\title{
Experimental evidence of chemical attraction in the mutualistic zebra mussel-killer shrimp system
}

\author{
Matteo Rolla $^{1}$, Sofia Consuegra ${ }^{1}$, Eleanor Carrington ${ }^{1}$, David J. Hall ${ }^{2}$, Carlos Garcia de Leaniz ${ }^{\text {Corresp. } 1}$ \\ ${ }^{1}$ Department of BioSciences, Centre for Sustainable Aquatic Research, Swansea University, Swansea, United Kingdom \\ 2 Cardiff Harbour Authority, Cardiff, United Kingdom \\ Corresponding Author: Carlos Garcia de Leaniz \\ Email address: c.garciadeleaniz@swansea.ac.uk
}

Invasion facilitation, whereby one species has a positive effect on the establishment of another species, could help explain the rapid colonisation shown by some freshwater invasive species, but the underlying mechanisms remain unclear. We employed two-choice test arenas to test whether the presence of zebra mussel (Dreissena polymorpha) could facilitate the establishment of the killer shrimp (Dikerogammarus villosus). Killer shrimp preferred to settle on mats of zebra mussel, but this was unrelated to mat size, and was not different from attraction shown to artificial grass, suggesting that zebra mussel primarily provides substrate and refuge to the killer shrimp. Killer shrimp were strongly attracted to water scented by zebra mussel, but not to water scented by fish. Chemical attraction to the zebra mussel's scent did not differ between sympatric and allopatric populations of killer shrimp, suggesting that chemical attraction is not an acquired or learned trait. Our study shows, for the first time, chemical attraction between two highly invasive freshwater species, thereby providing a plausible mechanism for invasion facilitation. This has implications for managing the spread of killer shrimp, and perhaps other freshwater invasive species, because chemical attraction could significantly increase establishment success in mutualistic systems. Failure to consider invasion facilitation may underestimate the risk of establishment, and likely also the impact of some aquatic invaders. 
1

2

3

4

5

6

7

8

9

10

11

12

\section{9}

\section{Experimental evidence of chemical attraction in the} mutualistic zebra mussel-killer shrimp system

4

${ }^{1}$ Department of BioSciences, Centre for Sustainable Aquatic Research, Swansea University, Singleton Park, Swansea SA2 8PP, UK *corresponding author: c.garciadeleaniz@swansea.ac.uk 


\section{Abstract}

15 Invasion facilitation, whereby one species has a positive effect on the establishment of another species, could help explain the rapid colonisation shown by some freshwater invasive species,

17 but the underlying mechanisms remain unclear. We employed two-choice test arenas to test whether the presence of zebra mussel (Dreissena polymorpha) could facilitate the establishment of the killer shrimp (Dikerogammarus villosus). Killer shrimp preferred to settle on mats of zebra mussel, but this was unrelated to mat size, and was not different from attraction shown to artificial grass, suggesting that zebra mussel primarily provides substrate and refuge to the killer shrimp. Killer shrimp were strongly attracted to water scented by zebra mussel, but not to water scented by fish. Chemical attraction to the zebra mussel's scent did not differ between sympatric and allopatric populations of killer shrimp, suggesting that chemical attraction is not an acquired or learned trait. Our study shows, for the first time, chemical attraction between two highly invasive freshwater species, thereby providing a plausible mechanism for invasion facilitation.

27 This has implications for managing the spread of killer shrimp, and perhaps other freshwater invasive species, because chemical attraction could significantly increase establishment success in mutualistic systems. Failure to consider invasion facilitation may underestimate the risk of establishment, and likely also the impact of some aquatic invaders.

Keywords 


\section{Introduction}

The impact of biological invasions has often been examined in isolation, under the implicit assumption that invaders do not interact with each other (Consuegra et al. 2011; Vanhaecke et al. 2015; Young et al. 2010; Young et al. 2009). However, invasion facilitation, whereby one species has a positive effect on the introduction, establishment or dispersal of other invasive species, is well documented, particularly in terrestrial plants and animals (Adams et al. 2003; Altieri et al. 2010). For example, the presence of the European honey bee (Apis mellifera) has increased the reproduction success of the invasive shrub Lantana camara in Australia (Goulson \& Derwent 2004), and similar positive synergies among invasive species have also been reported across many taxa (Woodward et al. 1990). This led Simberloff \& Von Holle (1999) to coin the term 'invasional meltdown' to describe the process by which the negative impacts triggered by one invasive species could be exacerbated by the interactions with other exotic species (Simberloff 2006).

However, invasion facilitation has not received as much attention in freshwater habitats as it has in terrestrial ecosystems, possibly because it is more difficult to detect (Ricciardi 2005), and because it typically only benefits one species (i.e. commensalism, (Laihonen \& Furman 1986; Ricciardi 2005). This lack of information is unfortunate because freshwater habitats, particularly lakes and ponds, rank among the most threatened ecosystems in the world, and this makes them particularly vulnerable to the threat of aquatic invasive species (AIS; Dudgeon et al. 2006). Habitat suitability models for invasive species, as well as risk maps (Crall et al. 2013; Jiménez-Valverde et al. 2011), rarely take into account the fact that some invaders can bioengineer their new habitat to suit their needs, or that the presence of one invasive species may make the habitat more attractive to other invaders (Strayer 2012). Thus, the synergistic effects of 
58 invasive species and their cumulative impacts on native fauna may be underestimated in aquatic

59 habitats if invasion facilitation exists and is not taken into account.

60

61

62

63

64

65

66

67

68

69

70

71

72

73

74

75

76

77

78

79

Two aquatic invaders that often occur together and may benefit from invasion facilitation are the zebra mussel (Dreissena polymorpha) and the killer shrimp (Dikerogammarus villosus).

The two species are included in the 100 worst invasive species in Europe (www.europe-

aliens.org), and in the case of zebra mussel, in the world (Lowe et al. 2000). Zebra mussels form dense mats on natural and artificial substrates which require expensive eradication programmes (Lovell et al. 2006), and compete directly for food and space with native bivalves (Fahnenstiel et al. 1995a; Fahnenstiel et al. 1995b; Johengen et al. 1995), sometimes driving them to extinction (Baker \& Hornbach 1997). The killer shrimp, on the other hand, has the typical profile of an efficient and plastic invader (Rewicz et al. 2014; Rossano et al. 2013), being able to adapt to a wide range of waters and conditions (Piscart et al. 2003). Its wide diet includes many macroinvertebrates, including native gammarids, which may be displaced and driven to local extinction (Dick \& Platvoet 2000; Piscart et al. 2003).

Both species share a broad, common Ponto-Caspian geographical origin, but the extent of sympatry in their native, as well as in the invaded areas, is unclear. The zebra mussel was first reported in Europe during the nineteenth century, becoming highly invasive and forming large populations (Son 2007). In contrast, the killer shrimp is a much more recent invader, it has only been detected in Europe during the last 20 years, but has spread rapidly ever since (MacNeil et al. 2010; Rewicz et al. 2014; Rewicz et al. 2017; Tricarico et al. 2010).

While many of the sites colonised by the killer shrimp in Europe had already established populations of zebra mussel, that might be indicative of invasion facilitation (Gallardo \& Aldridge 2015), the killer shrimp has also invaded many areas devoid of zebra mussel (Rewicz et 
81 al. 2015; van der Velde et al. 2010). Thus, whether there have been synergies in the

82

83

84

85

86

87

88

89

90

91

92

93

94

95

96

97

98

99

100

101

102

103

establishment of these two species is not clear (Devin et al. 2003). The zebra mussel has shown mutualistic interactions with one gastropod (Ricciardi 2005; Ricciardi et al. 1997), and two macrophytes (MacIsaac 1996; Skubinna et al. 1995), and can benefit the killer shrimp in various ways. For example, the dense interstitial matrix formed by the shells of zebra mussels may provide refuge for the killer shrimp (Ricciardi et al. 1997), allowing it to survive outside the water, while the production of faeces and pseudo faeces may provide food (Gergs \& Rothhaupt 2008a; Gergs \& Rothhaupt 2008b; Ricciardi et al. 1997; Stewart et al. 1998b). Similarly, zebra mussel larvae can attach to the hard chitin cover of the killer shrimp which could facilitate their dispersal (Kenderov 2017; Yohannes et al. 2017).

Given their common geographical origin, and recent evidence suggesting that the two species often occur together and might benefit each other, we hypothesized that killer shrimp might be chemically attracted to the presence of zebra mussel. We further hypothesized that attraction might differ depending on whether killer shrimp were found in habitats already colonised by the zebra mussel, i.e. whether attraction differed between sympatric and allopatric conditions.

Previous studies had indicated that mussel beds may provide killer shrimp with food and shelter (Gergs \& Rothhaupt 2008a; Gergs \& Rothhaupt 2008b), but two-choice preference tests yielded contradictory results (Gergs \& Rothhaupt 2008a), and did not consider the effects of coexistence or group dynamics on killer shrimp behaviour (Truhlar \& Aldridge 2015). We therefore employed an experimental approach to examine the attraction of killer shrimp to zebra mussel, considering potential differences between sympatric and allopatric populations, and individual versus group behaviour. In the first experiment we tested if killer shrimp had a 
104 preference for high densities of zebra mussels, as one might expect from a mutualistic system. In 105 the second experiment, we tested if killer shrimp had a preference for live zebra mussels 106 compared to empty shells or an artificial substrate, and whether this was affected by group 107 behaviour, as one might expect if attraction was mostly driven by food, and not by cover; in the 108 third experiment we tested if killer shrimp could detect the presence of zebra mussel through 109 chemical cues in the water, and whether this depended on past coexistence. Ultimately, our aim 110 was to address some of the underlying mechanisms of invasion facilitation as this might help 111 design better predictive models and more effective control measures of these two aquatic 112 invaders. 


\section{Materials and Methods}

115 Collection and origin of samples

116 Sympatric zebra mussel and killer shrimp were collected from Cardiff Bay (Cardiff, UK - Grid 117 reference: ST 19210 73510) in April 2016, whereas allopatric killer shrimp were collected from 118 the Upper Mother Ditch (Margam, UK, Grid reference: SS 79029 85506) in September 2016, 119 where the zebra mussel is not yet present (Figure 1). These were brought to the CSAR facilities 120 at Swansea University and maintained in 6 x 20 L tanks fed by separated recirculation 121 aquaculture systems, with a weekly replacement of c. $20 \%$ volume. Zebra mussels $(\sim 2.4 \mathrm{~kg})$ 122 were fed three times per week with a 2L mixture of Scenedesmus sp. and Chlorella sp., while 123 killer shrimps $(\sim 100 \mathrm{~g})$ were fed three times per week with $6 \mathrm{~g}$ of frozen bloodworms. Water 124 temperature was maintained at $15-16.5^{\circ} \mathrm{C}$. The killer shrimp used in the tests had an average size 125 of $16.8 \pm 0.9 \mathrm{~mm}$ and were tested at water temperature ranging between $15.4{ }^{\circ} \mathrm{C}$ and $16.2{ }^{\circ} \mathrm{C}$.

127 Experiment 1. Preference by killer shrimp of zebra mussel density

128 To test if killer shrimp had a preferred density of zebra mussel to settle on, we employed a 3L 129 tank (L25 x H 10 x W12 cm; Figure 2A) divided into two equal sections, each with a different 130 density of zebra mussel $(0,33,67$, or $100 \%$ cover $)$, and an acclimatisation plastic cylinder in the 131 middle. Individual killer shrimp $(n=96)$ were allowed to acclimatise for five minutes in the 132 cylinder, then the cylinder was lifted and the position and behaviour (swimming or hiding) of the 133 shrimp after 20 minutes was recorded. We assumed that if the shrimp was hiding it meant it had 134 found a suitable substrate, whereas if it was still swimming it meant it was still looking for a 135 refuge. We tested the killer shrimp's binary choice over six matched densities $(n=16)$ of zebra 
136 mussel: $0-33 \%, 0-66 \%, 0-100 \%, 33-66 \%, 33-100 \%$, and $66-100 \%$ employing a total of 96

137 specimens, and allocating the densities to the left or right sides of the test arena at random. 138

139 Experiment 2. Preference for zebra mussel over an artificial substrate

140 To test if the attraction of killer shrimp for zebra mussel-beds was simply related to the presence

141 of cover or to other factors (such as bio-deposited material) we compared preference for living

142 shells against either empty shells of zebra mussel or artificial grass (PE thickness $15 \mathrm{~mm})$ of

143 similar texture and extent of refuge. We used one killer shrimp per trial $(n=30)$, and then twenty

144 killer shrimp per trial $(n=80)$ to understand if substrate choice was affected by group dynamics.

145 The experimental protocol was the same as in Experiment 1, but in this case each side of the test 146 arena afforded 50\% cover and we used a 20 L test tank (L40 x H15 x W35 cm).

Experiment 3. Chemical attraction to zebra mussel

149 To test if killer shrimp was chemically attracted to the scent of zebra mussel we employed a 150 simplified version of the two-choice Perspex fluviarium used by Kroon (2005) in the preference 151 of another crustacean (Figure 2B). The fluviarium consisted of an acclimatization chamber (L5 x H6.5 x W5 cm) and two 0.3L choice chambers (L20 x H6.5 x W10 cm) with a total volume of approximately $0.7 \mathrm{~L}$. We tested preferences against dechlorinated tap water (blank), water scented with zebra mussel and Nile tilapia (Oreochromis niloticus) to control for possible attraction to organic matter, as well as blank water vs blank water to control for chamber bias. Individual killer shrimp were allowed to acclimatize for five minutes, the valves connected to the two water inlets were opened, the gate was lifted, and the time spent in each chamber was recorded for 15 minutes with a GoPro Hero camera. We compared the time spent in each arm as 
159 well as the number of transitions between arms as a measure of activity. Scent drip dosage was 160 adjusted at $200 \mathrm{ml} / \mathrm{min}$.

161 To prepare the scented water we placed either zebra mussels or fish (tilapia) in a tank

162 filled with dechlorinated water for 24 hours at a biomass of $50 \mathrm{~g} / \mathrm{L}$. The fluviarium was drained,

163 cleaned with $90 \%$ ethanol and rinsed with fresh water between trials to remove potential

164 chemical cues that could affect the next experiment. We repeated the experiment with killer

165 shrimp originating from a population living in sympatry (Cardiff Bay, $n=60$ ) or allopatry

166 (Margam, $n=60$ ) with zebra mussels. All the zebra mussel came from Cardiff Bay.

167

168

169

170

171

172

173

174

175

176

177

178

179

180

181

\section{Statistical analysis}

We used R 3.3 (R Core Team, 2017) for all analysis. In experiments 1 and 2, we used a generalized linear model (GLM) with a binomial log-link to test if the number of killer shrimp in the scented arm differed with treatment, and we then used a two-sided binomial test to assess if there was a statistically significant preference for the high or low density (Experiment 1) or different substrate combinations (Experiment 2) at each binary choice comparison. For Experiment 3 (two-way choice fluviarium), we used a linear model with time spent in the scented arm as the dependent variable and origin (allopatry vs sympatry) and type of scent (blank, zebra mussel, tilapia) as the predictors; we then used paired t-tests to assess which type of matched scent comparisons was statistically significant.

\section{Ethics Statement}

Zebra mussels and killer shrimp were collected under sampling permit CHA-01042016 from the Cardiff Water Authority. All experiments were carried out in accordance with Swansea 
182 University Ethical guidelines and were approved by the College of Science Ethics Committee 183 (300419/1557). Water removed from the experimental system was treated with bleach before 184 disposing, to avoid accidental dispersion of zebra mussel larvae.

185

186 


\section{Results}

188 Experiment 1. Preferred zebra mussel densities

189 Preference for zebra mussel varied depending on the densities being compared $\left(\chi^{2}=29.09, \mathrm{df}=\right.$ $1901, P<0.001)$. Killer shrimp showed a clear preference for the side of the tank with zebra mussel 191 when the alternative was a bare tank bottom (Figure 3A-C; binomial proportion test: $0-33 \% P=$ $1920.004 ; 0-66 \% P<0.001 ; 0-100 \% P<0.001)$. However, when both sides of the test arena had 193 different densities of zebra mussel, killer shrimp showed no preference (Figure 3D,F; binomial 194 proportion test $33-66 \%, \mathrm{P}=0.454 ; 66-100 \%, P=1.00$ ) or preferred the lower density (Figure 3E; $19533-100 \%, P=0.004)$. After 20 minutes, the majority of killer shrimp (85/96 or 88.5\%) were 196 found to be hiding, rather than swimming (binomial proportion test $P<0.001$ ) regardless of 197 treatment $\left(\chi^{2}=1.745, \mathrm{df}=1, P=0.883\right)$.

\section{Experiment 2. Substrate preference}

200 When tested individually, killer shrimp did not prefer live zebra mussels over artificial grass 201 (Figure 4A; binomial proportion test, $P=0.584$ ), or over empty zebra mussel shells (binomial 202 proportion test, $P=0.200$; Figure 4B). The majority of individuals were found hiding (rather than swimming), both when the comparison was against artificial grass (binomial proportion test, $83.3 \% P<0.001$ ) and also when there were empty shells (binomial proportion test, $76.6 \% P=$ $0.005)$.

However, when the experiment was repeated with 20 shrimp per trial (4 trials or 80 shrimp), killer shrimp strongly preferred the zebra mussel substrate over artificial grass (Figure $4 \mathrm{C}$; binomial proportion test, $P=0.006$ ) and also over empty shells (Figure 4D; binomial proportion test, $P=0.006$ ). As before, at the end the trials the majority of individuals were 
210 hiding, both when the comparison was against artificial grass (binomial proportion test, $77.5 \% P$

$211<0.001$ ) and also against empty shells (binomial proportion test, $72.5 \% P=0.006$ ).

212

213 Experiment 3. Chemical attraction to zebra mussel

214 No side preference was detected when killer shrimp were tested against blank water in both arms

215 of the 2-choice fluviarium, either in the sympatric $\left(t_{9}=1.343, P=0.212\right.$; Figure $\left.5 \mathrm{~A}\right)$ or allopatric

216 killer shrimp populations $\left(t_{19}=-1.280, P=0.216\right.$; Figure $\left.5 \mathrm{~B}\right)$, indicating that there was no side

217 bias. When killer shrimp were tested against water conditioned with tilapia scent, no preference

218 was observed over blank water, either in sympatry $\left(t_{19}=0.819, P=0.423\right.$; Figure $\left.5 \mathrm{C}\right)$ or

219 allopatry $\left(t_{19}=-0.687, P=0.500\right.$; Figure 5D). However, when killer shrimp were tested against

220 water conditioned with zebra mussel scent, there was a strong chemical attraction to the zebra

221 mussel scent, both in the sympatric $\left(t_{27}=-2.176, P=0.038\right.$; Figure 5E) and allopatric population

$222\left(t_{19}=-2.614, P=0.017\right.$; Figure 5F). Chemical attraction for zebra mussel scent was equally

223 strong in the sympatric and allopatric populations $\left(F_{1,118}=1.036, P=0.311\right)$.

224 The analysis of activity (measured as the number of transitions between arms) indicates that

225 activity was influenced by the type of test scent (Figure 6), as killer shrimp made more changes

226 when both arms were dosed with blank water than when one arm was dosed with zebra mussel

227 scent $(P=0.002)$ or tilapia scent $(P<0.001)$. No difference in activity was observed when killer

228 shrimp were presented with the scent of zebra mussel or the tilapia scent against blank water $(P$

$229=0.759)$. Overall, the sympatric population made more choices and was more active than the

230 allopatric population $(P=0.005)$.

231

232

Peer] reviewing PDF | (2019:05:37294:1:1:NEW 8 Oct 2019) 


\section{Discussion}

234 Our study provides novel experimental insights into some of the potential underlying reasons for 235 the joint occurrence of zebra mussel and the killer shrimp, two of the world's worst aquatic

236 invaders (Lowe et al. 2000). We found that killer shrimp showed a strong tendency for hiding in

237 zebra mussel beds, and were also chemically attracted to the scent of zebra mussels, which may

238 facilitate their invasion.

239 In our experiments, killer shrimp consistently avoided the empty side of the tank

240 (substrate coverage $0 \%$ ) that did not afford any refuge, and generally preferred to settle on zebra 241 mussel beds, even when tested with blank water and without any threat of predation. The strong

242 preference for a substrate that offers refuge is in agreement with observations under natural

243 conditions, where the species is typically found living among gravel, cobbles and boulders, and

244 absent in places where there is silt or substrates that do not afford refuge (Boets et al. 2010;

245 MacNeil et al. 2010). While juvenile killer shrimp may also be found living among macrophytes

246 (Devin et al. 2003), as happens for juveniles of several other predatory amphipods (Berezina

247 2007), adults tend to prefer hard substrates of large grain size, including cobble and roots (Devin 248 et al. 2003), pebbles (Van Riel et al. 2009), fissured stones (Kley et al. 2009), and coarse gravel

249 (Boets et al. 2010). Kobak et al. (2015) have suggested that the substrate preference of the killer

250 shrimp is size dependent and determined by the interstitial spaces of the substrate, as this

251 influences ease of movement and the ability to find refuge. The species appears to choose

252 fissures that closely match its body size (Platvoet et al. 2009), which might explain why they

253 prefer larger substrates as they become older. In this sense, zebra mussel beds provide an ideal

254 refuge for juveniles and adults alike, because as the mussels grow the interstitial spaces also 255 become larger. 
257 mussel over other textured substrates, are more difficult to interpret as different results were

258

obtained depending on group size. When killer shrimp were tested singly, no preference was detected for live zebra mussels over empty shells or artificial grass of similar texture, suggesting that substrate preference was mainly governed by the availability of refuge, which previous experiments have shown confers protection from fish predators (Kinzler \& Maier 2006).

However, when groups of twenty shrimp were tested, a strong preference for live zebra mussel over other substrates was found, suggesting the existence of group behaviour that cannot solely be explained by refuge availability and deserves further investigation. Killer shrimp tend to form aggregations, and these are thought to be advantageous and increase the chances of successfully colonising new areas (Truhlar \& Aldridge 2015). However, while group behaviour can increase fitness and reproductive success (Réale et al. 2007), it can also facilitate intraspecific predation (cannibalism), which is frequently observed in amphipods (Dick et al. 1993; Hunte \& Myers 1984; Ward 1985), including the killer shrimp (Dick \& Platvoet 2000; Dick et al. 2002; MacNeil et al. 1997). An inverse association may exist between sociability and cannibalism in amphipods (Kinzler et al. 2009; Truhlar \& Aldridge 2015), although this may also be influenced by predation pressure (Dick et al. 1993). Cannibalism in killer shrimp does not appear to be so strong as to reduce the species' sociability, possibly because cannibalism mainly targets small juveniles (Kinzler \& Maier 2003) which tend to be spatially segregated from larger adults that could prey on them (Devin et al. 2003).

One novel finding of our study was the strong chemical attraction shown by killer shrimp to the scent of live zebra mussels (or something associated with them), a response not seen to blank water or the scent of non-predatory fish. Amphipods use chemical cues as their main form 
279 of communicating between conspecifics (Thiel 2011), and also to recognize and avoid predators

280 (Wooster 1998), but chemical attraction in contexts other than conspecific recognition or prey-

281 predator interactions has, to our knowledge, not been reported before. A previous two-choice

282 study reported chemical avoidance of zebra mussel scent by killer shrimp, but this was tested

283 using water from a lake known to contain many predatory fish (Gergs \& Rothhaupt 2008a).

284 Chemical detection in amphipods is mediated mainly via specific sensillae located on the

285 antennae (reviewed by Hallberg \& Skog 2011) and is used in mate choice and species

286 discrimination, reducing the chances of interspecific mating between similar species (Cothran et

287 al. 2013; Dick \& Elwood 1990). Chemical cues are also used by females to recognize and defend

288 their offspring against conspecifics (Mattson \& Cedhagen 1989), and some amphipods can also

289 recognize alarm cues from damaged conspecifics and mount a strong freezing response as an

290 anti-predatory strategy (Sehr \& Gall 2016). Killer shrimp have been reported to use chemical

291 cues to recognize and avoid potential predators such as the spiny-cheek crayfish Orconectes

292 limosus (Hesselschwerdt et al. 2009), the European bullhead Cottus gobio (Sornom et al. 2012)

293 and the racer goby Babka gymnotrachelus (Jermacz et al. 2017). Our study shows that killer

294 shrimp can also use chemical cues to find zebra mussels that provide not only cover and refuge

295 (Ricciardi et al. 1997), but also food through the production of faeces and pseudo faeces (Gergs

296 \& Rothhaupt 2008a; Gergs \& Rothhaupt 2008b; Ricciardi et al. 1997; Stewart et al. 1998a).

297 A preference for settling in zebra mussel beds was only manifested in our study when

298 killer shrimp were tested in groups, not when they were tested singly, which serves to highlight

299 the need to take group dynamics into account in behavioural studies of social gammarids

300 (Williams et al. 2016). The preference for zebra mussel beds shown by the killer shrimp (at least

301 when they are tested in groups), and the fact that they are strongly attracted to the zebra mussel 
302 scent, suggests that this could be an example of invasion facilitation, as seen in other studies. For

303 example, positive synergies resulting in invasion facilitation have been reported for an invasive

304 algae and an invasive bryozoan (Levin et al. 2002), as well as among invasive fish parasites

305 (Hohenadler et al. 2018). Other well known examples of invasion facilitation, include the

306 bullfrog-sunfish system, where the survival of the invasive bullfrog (Rana catesbeiana) was

307 enhanced by the presence of the non-native bluegill sunfish (Lepomis macrochirus) because the

308 latter preyed on native dragonfly which in turn preyed on bullfrog tadpoles (Adams et al. 2003).

309 Similarly, predation by an invasive crab on a large native clam resulted in the spread of a smaller

310 invasive clam due to competitive release (Grosholz 2005).

Our study indicates that chemical attraction by the killer shrimp to the zebra mussel scent

312

313

314

315

316

317

\section{Conclusion}

319

320

321

322

323

324 further studies.

was as strong under sympatric as it was under allopatric conditions, suggesting this is not a

recently acquired or learned trait, but rather an older behavioural adaptation. However, the absence of population replication (it is very difficult to find populations of killer shrimp that do not coexist with zebra mussel) makes it difficult to draw firm conclusions and would warrant

In general, mutualist interactions are less well studied than competitive ones (Simberloff \& Von Holle 1999), and interactions between invasive species are less well known than those between invasive and native species (Gallardo \& Aldridge 2018). There is still limited knowledge on positive interactions among invasive species, despite the fact that this may hold the key for more effective control of new invasions. Given the strong preference for settling on zebra mussel mats, and the benefits that this entails (Gergs \& Rothhaupt 2008b; MacNeil et al. 2008) - including not 
325 just refuge, but also benthic organic matter that can be a source of food (Ricciardi et al. 1997;

326 Stewart et al. 1998b), chemical attraction may help understand synergies between these two

327 invasive species. Chemical attraction may need to be taken into account in the study of patterns

328 of distribution of these two invasive species, since the presence of zebra mussel could make the

329 killer shrimp more likely to become established, and hence a more successful invader. For

330 example, chemical attraction to zebra mussels could help the establishment success of killer

331 shrimp by decreasing search time for food and shelter. The zebra mussel's ability to settle on a

332 wide range of substrate (Marsden \& Lansky 2000) and bioengineer its own environment (Mayer

333 et al. 2001) can turn formerly unsuitable habitats into favourable locations for killer shrimp

334 settlement, expanding the potential range of suitable environments. For example, the NBN Atlas

335 (https://nbnatlas.org/), the UK's largest biodiversity database, holds 3,182 records of zebra

336 mussel but only 317 observations of killer shrimp and information on the presence of zebra

337 mussel could help make more accurate predictions of the likely spread of killer shrimp. This is of

338 particular concern when the species is a recent invader since there is typically insufficient

339 information to predict areas at risk or to guide management (Morales et al. 2017). In Great

340 Britain, the killer shrimp was first detected in 2010 (Rewicz et al. 2014) and is only present in 8

341 locations, making it difficult to predict its future dispersal (Rodríguez-Rey et al. 2019). The

342 zebra mussel, in contrast, was first detected in 1824 and is now established in 376 locations in

343 England and Wales (Aldridge et al. 2004; Rodríguez-Rey et al. 2019), potentially increasing the

344 number of favourable locations for killer shrimp many fold. Yet, current invasive species

345 prioritisation lists (Boets et al. 2014; Carboneras et al. 2018) and risk assessment guidelines (Roy

346 et al. 2018) tend to view invasive species in isolation, making no allowance for invasion

347 facilitation. Our study suggests that information on the presence of zebra mussel should be 
348 incorporated into risk maps and models of killer shrimp dispersal, because ignoring chemical

349 attraction will likely underestimate the extent and consequences of invasion facilitation.

\section{Acknowledgments}

352

353

354

355

356

357

358

359

360

361

362

363

364

365

366

367

368

369

370

371

372

373

374

375

376

We are grateful to Teja Muha (Swansea University), Emma Keenan and Graham Rutt (Natural

Resources Wales) for help with the sampling and to Josh Jones for help with yhe maps. Funding was provided by the EC Horizon 2020 Aquainvad-ED project (Marie Sklodowska-Curie ITN2014-ETN-642197) to SC.

\section{Author Contributions \& Competing Interests}

CGL and SC designed the study and secured the funding. MR and EC collected the data and carried out the analyses with advice from CGL. CGL and MR wrote the MS with contributions from $\mathrm{SC}$ and $\mathrm{DH}$. The authors declare no competing interests.

\section{References}

Adams MJ, Pearl CA, and Bruce Bury R. 2003. Indirect facilitation of an anuran invasion by non-native fishes. Ecology Letters 6:343-351.

Aldridge DC, Elliott P, and Moggridge GD. 2004. The recent and rapid spread of the zebra mussel (Dreissena polymorpha) in Great Britain. Biological Conservation 119:253-261.

Altieri AH, van Wesenbeeck BK, Bertness MD, and Silliman BR. 2010. Facilitation cascade drives positive relationship between native biodiversity and invasion success. Ecology 91:12691275.

Baker S, and Hornbach D. 1997. Acute physiological effects of zebra mussel (Dreissena polymorpha) infestation on two unionid mussels, Actiononaias ligamentina and Amblema plicata. Canadian Journal of Fisheries and Aquatic Sciences 54:512-519.

Berezina NA. 2007. Invasions of alien amphipods (Amphipoda: Gammaridea) in aquatic ecosystems of North-Western Russia: pathways and consequences. Hydrobiologia 590:1529. 
Boets P, Lock K, Messiaen M, and Goethals PL. 2010. Combining data-driven methods and lab studies to analyse the ecology of Dikerogammarus villosus. Ecological Informatics 5:133139.

Boets P, Pauwels IS, Lock K, and Goethals PLM. 2014. Using an integrated modelling approach for risk assessment of the killer shrimp 'Dikerogammarus villosus'. River Research and Applications 30:403-412. 10.1002/rra.2658

Carboneras C, Genovesi P, Vilà M, Blackburn TM, Carrete M, Clavero M, D'hondt B, Orueta JF, Gallardo B, and Geraldes P. 2018. A prioritised list of invasive alien species to assist the effective implementation of EU legislation. Journal of Applied Ecology 55:539-547.

Consuegra S, Phillips N, Gajardo G, and Garcia de Leaniz C. 2011. Winning the invasion roulette: Escapes from fish farms increase admixture and facilitate establishment of non-native rainbow trout. Evolutionary Applications 4:660-671.

Cothran RD, Henderson KA, Schmidenberg D, and Relyea RA. 2013. Phenotypically similar but ecologically distinct: differences in competitive ability and predation risk among amphipods. Oikos 122:1429-1440.

Crall AW, Jarnevich CS, Panke B, Young N, Renz M, and Morisette J. 2013. Using habitat suitability models to target invasive plant species surveys. Ecological Applications 23:6072.

Devin S, Piscart C, Beisel J-N, and Moreteau J. 2003. Ecological traits of the amphipod invader Dikerogammarus villosus on a mesohabitat scale. Archiv für Hydrobiologie 158:43-56.

Dick JT, and Elwood RW. 1990. Symmetrical assessment of female quality by male Gammarus pulex (Amphipoda) during struggles over precopula females. Animal Behaviour 40:877883.

Dick JT, Montgomery I, and Elwood RW. 1993. Replacement of the indigenous amphipod Gammarus duebeni celticus by the introduced G. pulex: differential cannibalism and mutual predation. Journal of Animal Ecology:79-88.

Dick JT, and Platvoet D. 2000. Invading predatory crustacean Dikerogammarus villosus eliminates both native and exotic species. Proceedings of the Royal Society of London Series B: Biological Sciences 267:977-983.

Dick JT, Platvoet D, and Kelly DW. 2002. Predatory impact of the freshwater invader Dikerogammarus villosus (Crustacea: Amphipoda). Canadian Journal of Fisheries and Aquatic Sciences 59:1078-1084.

Dudgeon D, Arthington AH, Gessner MO, Kawabata Z-I, Knowler DJ, Lévêque C, Naiman RJ, Prieur-Richard A-H, Soto D, and Stiassny ML. 2006. Freshwater biodiversity: importance, threats, status and conservation challenges. Biological Reviews 81:163-182.

Fahnenstiel GL, Bridgeman TB, Lang GA, McCormick MJ, and Nalepa TF. 1995a. Phytoplankton productivity in Saginaw Bay, Lake Huron: effects of zebra mussel (Dreissena polymorpha) colonization. Journal of Great Lakes Research 21:464-475.

Fahnenstiel GL, Lang GA, Nalepa TF, and Johengen TH. 1995b. Effects of zebra mussel (Dreissena polymorpha) colonization on water quality parameters in Saginaw Bay, Lake Huron. Journal of Great Lakes Research 21:435-448.

Gallardo B, and Aldridge DC. 2015. Is Great Britain heading for a Ponto-Caspian invasional meltdown? Journal of Applied Ecology 52:41-49.

Gallardo B, and Aldridge DC. 2018. Inter-basin water transfers and the expansion of aquatic invasive species. Water Research 143:282-291. 
422

423

424

425

426

427

428

429

430

431

432

433

434

435

436

437

438

439

440

441

442

443

444

445

446

447

448

449

450

451

452

453

454

455

456

457

458

459

460

461

462

463

464

465

466

467

Gergs R, and Rothhaupt K-O. 2008a. Effects of zebra mussels on a native amphipod and the invasive Dikerogammarus villosus: the influence of biodeposition and structural complexity. Journal of the North American Benthological Society 27:541-548.

Gergs R, and Rothhaupt K-O. 2008b. Feeding rates, assimilation efficiencies and growth of two amphipod species on biodeposited material from zebra mussels. Freshwater Biology 53:2494-2503. 10.1111/j.1365-2427.2008.02077.x

Goulson D, and Derwent LC. 2004. Synergistic interactions between an exotic honeybee and an exotic weed: pollination of Lantana camara in Australia. Weed Research 44:195-202.

Grosholz ED. 2005. Recent biological invasion may hasten invasional meltdown by accelerating historical introductions. Proceedings of the National Academy of Sciences 102:1088-1091.

Hallberg E, and Skog M. 2011. Chemosensory sensilla in crustaceans. In: Breithaupt T, and Thiel M, eds. Chemical Communication in Crustaceans. New York, NY: Springer, 103 -121.

Hesselschwerdt J, Tscharner S, Necker J, and Wantzen KM. 2009. A local gammarid uses kairomones to avoid predation by the invasive crustaceans Dikerogammarus villosus and Orconectes limosus. Biological Invasions 11:2133.

Hohenadler M, Honka K, Emde S, Klimpel S, and Sures B. 2018. First evidence for a possible invasional meltdown among invasive fish parasites. Scientific Reports 8:15085.

Hunte W, and Myers R. 1984. Phototaxis and cannibalism in gammaridean amphipods. Marine Biology 81:75-79.

Jermacz Ł, Andrzejczak J, Arczyńska E, Zielska J, and Kobak J. 2017. An enemy of your enemy is your friend: Impact of predators on aggregation behavior of gammarids. Ethology 123:627-639.

Jiménez-Valverde A, Peterson AT, Soberón J, Overton J, Aragón P, and Lobo JM. 2011. Use of niche models in invasive species risk assessments. Biological Invasions 13:2785-2797.

Johengen TH, Nalepa TF, Fahnenstiel GL, and Goudy G. 1995. Nutrient changes in Saginaw Bay, Lake Huron, after the establishment of the zebra mussel (Dreissena polymorpha). Journal of Great Lakes Research 21:449-464.

Kenderov LA. 2017. An invader along with an invader: an unusual record of a zebra mussel Dreissena polymorpha (Pallas, 1771) (Bivalvia) living phoretically on a killer shrimp Dikerogammarus villosus (Sowinsky, 1894) (Amphipoda). Acta Zoologica Bulgarica Suppl. 9:287-291.

Kinzler W, Kley A, Mayer G, Waloszek D, and Maier G. 2009. Mutual predation between and cannibalism within several freshwater gammarids: Dikerogammarus villosus versus one native and three invasives. Aquatic Ecology 43:457.

Kinzler W, and Maier G. 2003. Asymmetry in mutual predation: possible reason for the replacement of native gammarids by invasives. Archiv für Hydrobiologie 157:473-481.

Kinzler W, and Maier G. 2006. Selective predation by fish: a further reason for the decline of native gammarids in the presence of invasives? Journal of Limnology 65:27-34.

Kley A, Kinzler W, Schank Y, Mayer G, Waloszek D, and Maier G. 2009. Influence of substrate preference and complexity on co-existence of two non-native gammarideans (Crustacea: Amphipoda). Aquatic Ecology 43:1047-1059.

Kobak J, Jermacz Ł, and Dzierżyńska-Białończyk A. 2015. Substratum preferences of the invasive killer shrimp Dikerogammarus villosus. Journal of Zoology 297:66-76. 10.1111/jzo.12252

Kroon FJ. 2005. Behavioural avoidance of acidified water by juveniles of four commercial fish and prawn species with migratory life stages. Marine Ecology Progress Series 285:193204.

Peer] reviewing PDF | (2019:05:37294:1:1:NEW 8 Oct 2019) 
468

469

470

471

472

473

474

475

476

477

478

479

480

481

482

483

484

485

486

487

488

489

490

491

492

493

494

495

496

497

498

499

500

501

502

503

504

505

506

507

508

509

510

511

512

Laihonen P, and Furman E. 1986. The site of settlement indicates commensalism between bluemussel and its epibiont. Oecologia 71:38-40.

Levin PS, Coyer JA, Petrik R, and Good TP. 2002. Community-wide effects of nonindigenous species on temperate rocky reefs. Ecology 83:3182-3193.

Lovell SJ, Stone SF, and Fernandez L. 2006. The economic impacts of aquatic invasive species: a review of the literature. Agricultural and Resource Economics Review 35:195-208.

Lowe S, Browne M, Boudjelas S, and De Poorter M. 2000. 100 of the world's worst invasive alien species: a selection from the global invasive species database: Invasive Species Specialist Group Auckland.

MacIsaac HJ. 1996. Potential abiotic and biotic impacts of zebra mussels on the inland waters of North America. American Zoologist 36:287-299.

MacNeil C, Dick JT, and Elwood RW. 1997. The trophic ecology of freshwater Gammarus spp.(Crustacea: Amphipoda): problems and perspectives concerning the functional feeding group concept. Biological Reviews 72:349-364.

MacNeil C, Platvoet D, and Dick JT. 2008. Potential roles for differential body size and microhabitat complexity in mediating biotic interactions within invasive freshwater amphipod assemblages. Fundamental and Applied Limnology/Archiv für Hydrobiologie 172:175-182.

MacNeil C, Platvoet D, Dick JTA, Fielding N, Constable A, Hall N, Aldridge D, Renals T, and Diamond M. 2010. The Ponto-Caspian 'killer shrimp', Dikerogammarus villosus (Sowinsky, 1894), invades the British Isles. Aquatic Invasions 5:441-445. 10.3391/ai.2010.5.4.15

Marsden JE, and Lansky DM. 2000. Substrate selection by settling zebra mussels, Dreissena polymorpha, relative to material, texture, orientation, and sunlight. Canadian Journal of Zoology 78:787-793.

Mattson S, and Cedhagen T. 1989. Aspects of the behaviour and ecology of Dyopedos monacanthus (Metzger) and D. porrectus Bate, with comparative notes on Dulichia tuberculata Boeck (Crustacea: Amphipoda: Podoceridae). Journal of Experimental Marine Biology and Ecology 127:253-272.

Mayer C, Rudstam L, Mills E, Cardiff S, and Bloom C. 2001. Zebra mussels (Dreissena polymorpha), habitat alteration, and yellow perch (Perca flavescens) foraging: systemwide effects and behavioural mechanisms. Canadian Journal of Fisheries and Aquatic Sciences 58:2459-2467.

Morales NS, Fernández IC, and Baca-González V. 2017. MaxEnt's parameter configuration and small samples: are we paying attention to recommendations? A systematic review. PeerJ 5:e3093. 10.7717/peerj.3093

Piscart C, Devin S, Beisel J-N, and Moreteau J-C. 2003. Growth-related life-history traits of an invasive gammarid species: evaluation with a Laird-Gompertz model. Canadian Journal of Zoology 81:2006-2014.

Platvoet D, Dick JTA, MacNeil C, van Riel MC, and van der Velde G. 2009. Invader-invader interactions in relation to environmental heterogeneity leads to zonation of two invasive amphipods, Dikerogammarus villosus (Sowinsky) and Gammarus tigrinus Sexton: amphipod pilot species project (AMPIS) report 6. Biological Invasions 11:2085-2093.

Réale D, Reader SM, Sol D, McDougall PT, and Dingemanse NJ. 2007. Integrating animal temperament within ecology and evolution. Biological Reviews 82:291-318. 
513

514

515

516

517

518

519

520

521

522

523

524

525

526

527

528

529

530

531

532

533

534

535

536

537

538

539

540

541

542

543

544

545

546

547

548

549

550

551

552

553

554

555

556

557

Rewicz T, Grabowski M, MacNeil C, and Bacela-Spychalska K. 2014. The profile of a 'perfect' invader--the case of killer shrimp, Dikerogammarus villosus. Aquatic Invasions 9:267288.

Rewicz T, Wattier R, Grabowski M, Rigaud T, and Bacela-Spychalska K. 2015. Out of the Black Sea: phylogeography of the invasive killer shrimp Dikerogammarus villosus across Europe. PLoS One 10:e0118121. 10.1371/journal.pone.0118121

Rewicz T, Wattier R, Rigaud T, Grabowski M, Mamos T, and Bącela-Spychalska K. 2017. The killer shrimp, Dikerogammarus villosus, invading European Alpine Lakes: A single main source but independent founder events with an overall loss of genetic diversity. Freshwater Biology 62:1036-1051. 10.1111/fwb.12923

Ricciardi A. 2005. Facilitation and synergistic interactions between introduced aquatic species. In: Mooney HA, Mack RN, McNeely JA, Neville LE, Schei PJ, and Waage J, eds. Invasive Alien Species: A New Synthesis: Island Press, 162-178.

Ricciardi A, Whoriskey FG, and Rasmussen JB. 1997. The role of the zebra mussel (Dreissena polymorpha) in structuring macroinvertebrate communities on hard substrata. Canadian Journal of Fisheries and Aquatic Sciences 54:2596-2608.

Rodríguez-Rey M, Consuegra S, Börger L, and Garcia de Leaniz C. 2019. Improving Species Distribution Modelling of freshwater invasive species for management applications. PLoS One 14:e217896.

Rossano C, Di Cristina G, and Scapini F. 2013. Life cycle and behavioural traits of Dikerogammarus villosus (Sowinsky, 1894)(Amphipoda, Gammaridae) colonising an artificial fresh water basin in Tuscany (central Italy). Crustaceana 86:908-931.

Roy HE, Rabitsch W, Scalera R, Stewart A, Gallardo B, Genovesi P, Essl F, Adriaens T, Bacher S, and Booy O. 2018. Developing a framework of minimum standards for the risk assessment of alien species. Journal of Applied Ecology 55:526-538.

Sehr EK, and Gall BG. 2016. Responses of an aquatic isopod and amphipod to chemical alarm cues from damaged conspecifics. Journal of Freshwater Ecology 31:231-237.

Simberloff D. 2006. Invasional meltdown 6 years later: important phenomenon, unfortunate metaphor, or both? Ecol Lett 9:912-919. 10.1111/j.1461-0248.2006.00939.x

Simberloff D, and Von Holle B. 1999. Positive interactions of nonindigenous species: invasional meltdown? Biological Invasions 1:21-32.

Skubinna JP, Coon TG, and Batterson TR. 1995. Increased abundance and depth of submersed macrophytes in response to decreased turbidity in Saginaw Bay, Lake Huron. Journal of Great Lakes Research 21:476-488.

Son MO. 2007. Native range of the zebra mussel and quagga mussel and new data on their invasions within the Ponto-Caspian Region. Aquatic Invasions 2:174-184.

Sornom P, Gismondi E, Vellinger C, Devin S, Férard J-F, and Beisel J-N. 2012. Effects of sublethal cadmium exposure on antipredator behavioural and antitoxic responses in the invasive amphipod Dikerogammarus villosus. PLoS One 7:e42435.

Stewart TW, Miner JG, and Lowe RL. 1998a. Macroinvertebrate communities on hard substrates in western Lake Erie: structuring effects of Dreissena. Journal of Great Lakes Research 24:868-879.

Stewart TW, Miner JG, and Lowe RL. 1998b. Quantifying mechanisms for zebra mussel effects on benthic macroinvertebrates: organic matter production and shell-generated habitat. Journal of the North American Benthological Society 17:81-94. 
558

559

560

561

562

563

564

565

566

567

568

569

570

571

572

573

574

575

576

577

578

579

580

581

582

583

584

585

586

587

588

589

590

591

592

593

594
Strayer DL. 2012. Eight questions about invasions and ecosystem functioning. Ecology Letters 15:1199-1210.

Thiel M. 2011. The evolution of sociality: peracarid crustaceans as model organisms. New frontiers in crustacean biology: Brill, 285-297.

Tricarico E, Mazza G, Orioli G, Rossano C, Scapini F, and Gherardi F. 2010. The killer shrimp, Dikerogammarus villosus (Sowinsky, 1894), is spreading in Italy. Aquatic Invasions 5:211-214. 10.3391/ai.2010.5.2.14

Truhlar AM, and Aldridge DC. 2015. Differences in behavioural traits between two potentially invasive amphipods, Dikerogammarus villosus and Gammarus pulex. Biological Invasions 17:1569-1579.

van der Velde G, Rajagopal S, and bij de Vaate A. 2010. The zebra mussel in Europe: Backhuys Leiden/Margraf, Weikersheim.

Van Riel M, Van der Velde G, and Bij de Vaate A. 2009. Interference competition between alien invasive gammaridean species. Biological Invasions 11:2119.

Vanhaecke D, Garcia de Leaniz C, Gajardo G, Dunham J, Giannico G, and Consuegra S. 2015. Genetic signatures of historical dispersal of fish threatened by biological invasions: the case of galaxiids in South America. Journal of Biogeography 42:1942-1952.

Ward PI. 1985. The breeding behaviour of Gammarus duebeni. Hydrobiologia 121:45-50.

Williams KL, Navins KC, and Lewis SE. 2016. Behavioral responses to predation risk in brooding female amphipods (Gammarus pseudolimnaeus). Journal of Freshwater Ecology 31:571581.

Woodward SA, Vitousek PM, Matson K, Hughes F, Benvenuto K, and Matson PA. 1990. Use of the exotic tree Myrica faya by native and exotic birds in Hawai'i Volcanoes National Park.

Wooster DE. 1998. Amphipod (Gammarus minus) responses to predators and predator impact on amphipod density. Oecologia 115:253-259.

Yohannes E, Ragg RB, Armbruster JP, and Rothhaupt K-O. 2017. Physical attachment of the invasive zebra mussel Dreissena polymorpha to the invasive gammarid Dikerogammarus villosus: supplementary path for invasion and expansion? Fundamental and Applied Limnology/Archiv für Hydrobiologie 191:79-85.

Young KA, Dunham JB, Stephenson JF, Terreau A, Thailly AF, Gajardo G, and Garcia de Leaniz C. 2010. A trial of two trouts: comparing the impacts of rainbow and brown trout on a native galaxiid. Animal Conservation 13:399-410.

Young KA, Stephenson J, Terreau A, Thailly A-F, Gajardo G, and Garcia de Leaniz C. 2009. The diversity of juvenile salmonids does not affect their competitive impact on a native galaxiid. Biological Invasions 11:1955-1961. 


\section{$595 \quad$ Figure legends}

596 Figure 1. Location of experimental killer shrimp populations living in sympatry (Cardiff Bay)

597 and allopatry (Upper Mother Ditch) with zebra mussel.

598

599

Figure 2. Experimental set up used to test substrate preferences of killer shrimp (A - side view; C

600

- top view) and chemical attraction to water scented by zebra mussel (B - side view; D - top

601 view).

602

603

Figure 3. Proportion of individual killer shrimp (binomial $95 \mathrm{CI}$ ) settling in zebra mussel beds of

604

different sizes in six binary choice tests $(A-F, n=16$ shrimp/test) involving different amount of

605

zebra mussel cover $(0,33,66$, and $100 \%$ tank cover $)$.

606

607

Figure 4. Proportion of killer shrimp (binomial $95 \mathrm{CI}$ ) settling in binary choice tests involving 608 different substrates (live zebra mussel, empty shells of zebra mussel, artificial grass) tested singly (A-B, $n=30$ shrimp/test) or in groups of 20 (C-D, $n=4$ tests).

610

611 Figure 5. Preference by individual killer shrimp (mean time spent, $\mathrm{s} \pm 95 \mathrm{CI}$ ) in water

612 conditioned with different scents (blank water, $\mathrm{n}=40$; tilapia scent, $\mathrm{n}=40$; zebra mussel scent, $613 \mathrm{n}=40)$ from sympatric $(\mathrm{A}, \mathrm{C}, \mathrm{E} ; \mathrm{n}=60)$ and allopatric $(\mathrm{B}, \mathrm{D}, \mathrm{F} ; \mathrm{n}=60)$ populations.

615 Figure 6. Activity (mean number of transitions $\pm 95 \mathrm{CI}$ ) of individual killer shrimp tested in 616 water conditioned with different scents (blank water, $\mathrm{n}=40$; tilapia scent, $\mathrm{n}=40$; zebra mussel 617 scent, $\mathrm{n}=40)$ from sympatric $(\mathrm{A} ; \mathrm{n}=60)$ and allopatric $(\mathrm{B} ; \mathrm{n}=60)$ populations. 
619

620 
Figure 1

Figure 1

Location of experimental killer shrimp populations living in sympatry (Cardiff Bay) and allopatry (Upper Mother Ditch) with zebra mussel.

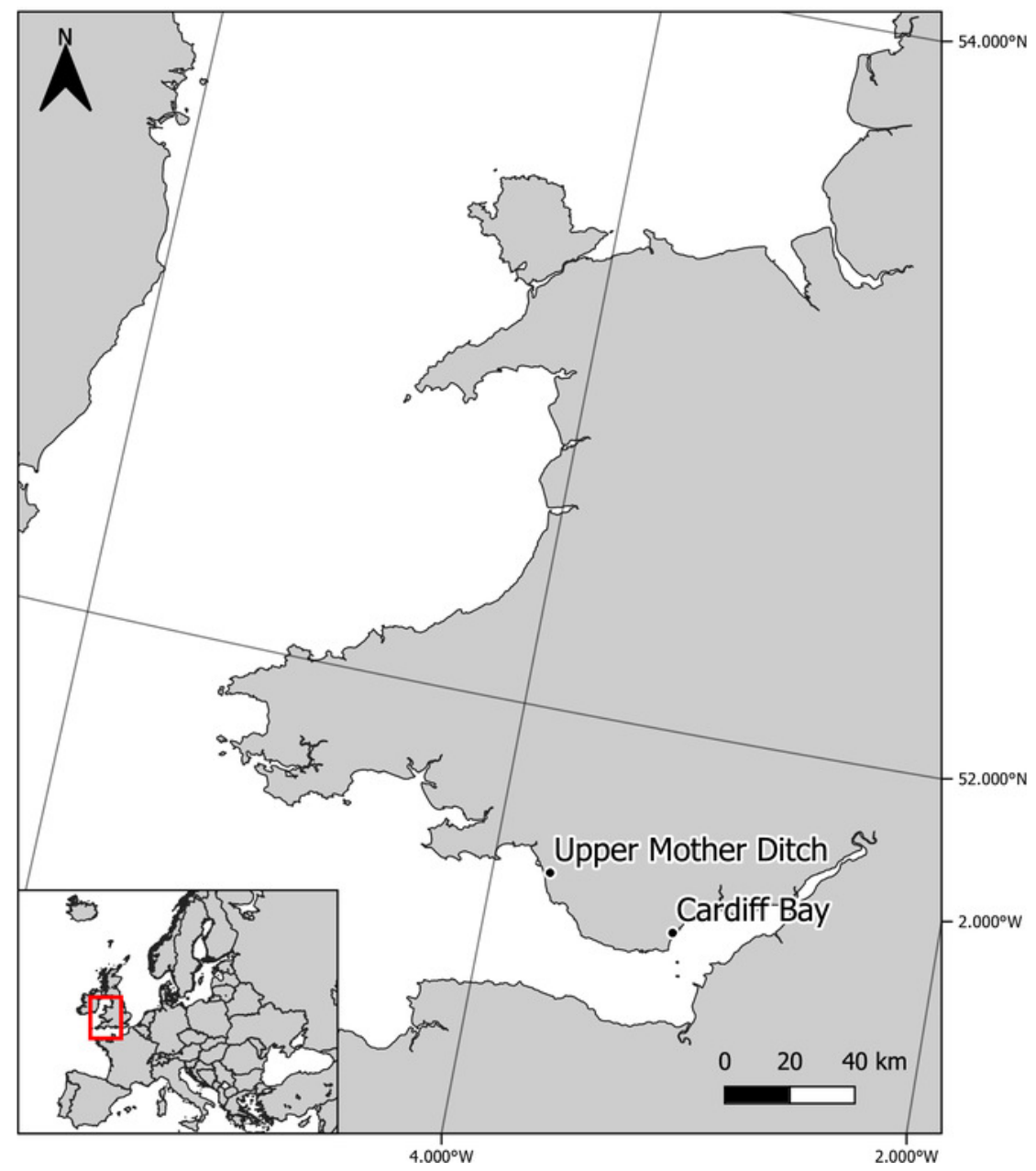


Figure 2

Figure 2

Figure 2. Experimental set up used to test substrate preferences of killer shrimp ( $A$ - side view; C - top view) and chemical attraction to water scented by zebra mussel (B - side view; D - top view).

A

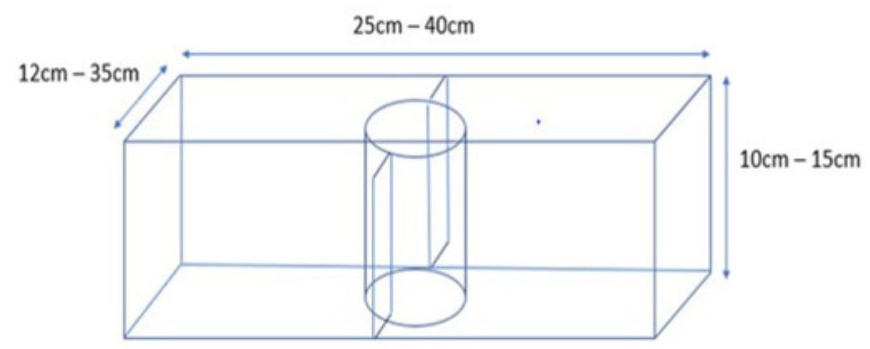

C

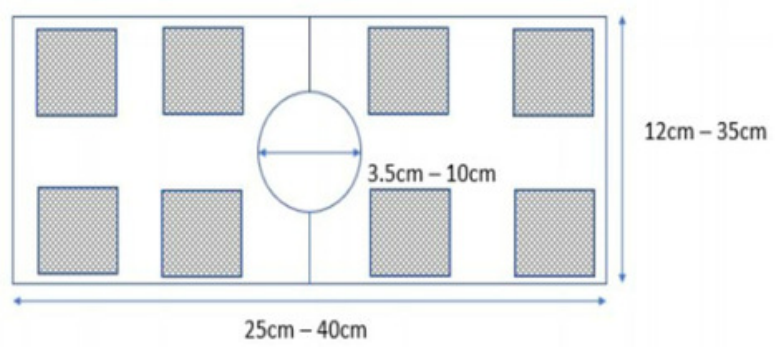

B

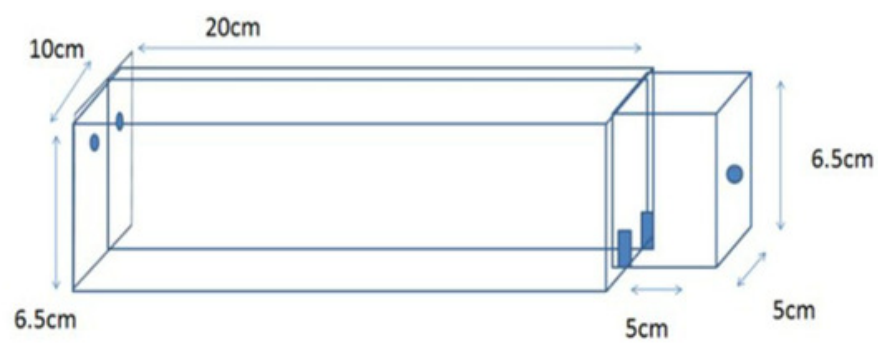

D

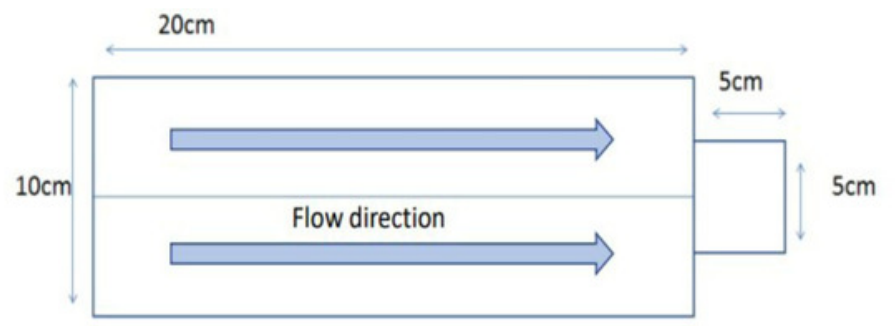




\section{Figure 3}

Figure 3

Figure 3. Proportion of individual killer shrimp (binomial $95 \mathrm{Cl}$ ) settling in zebra mussel beds of different sizes in six binary choice tests ( $A-F, n=16$ shrimp/test) involving different amount of zebra mussel cover $(0,33,66$, and $100 \%$ tank cover $)$. 
A

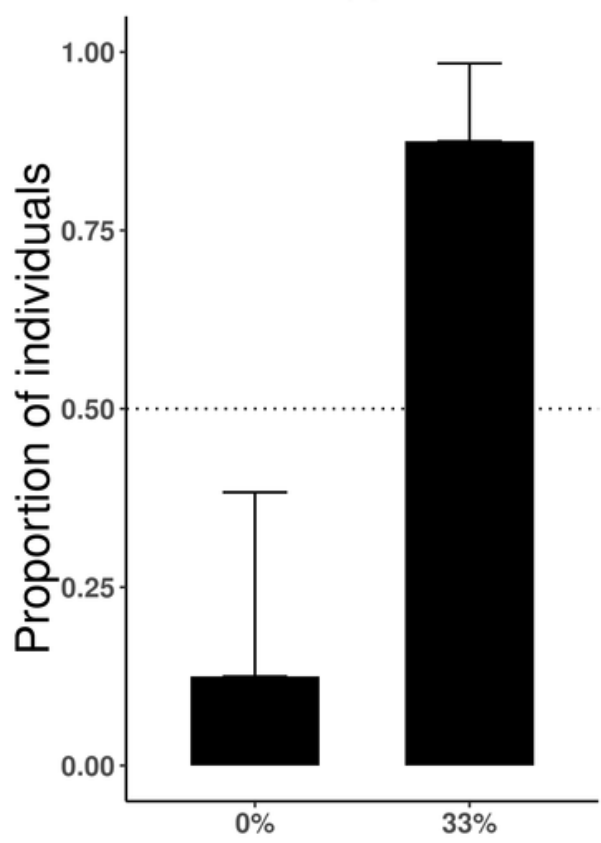

D

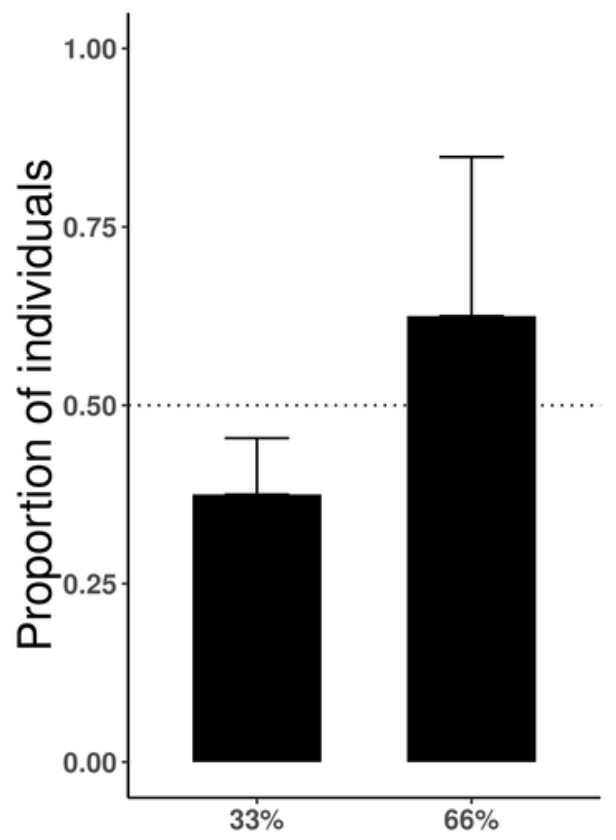

B

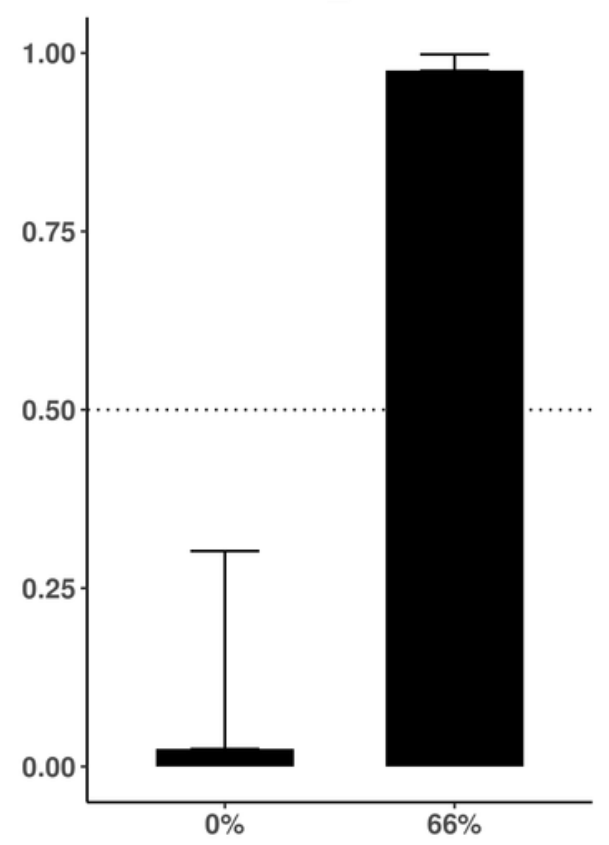

E

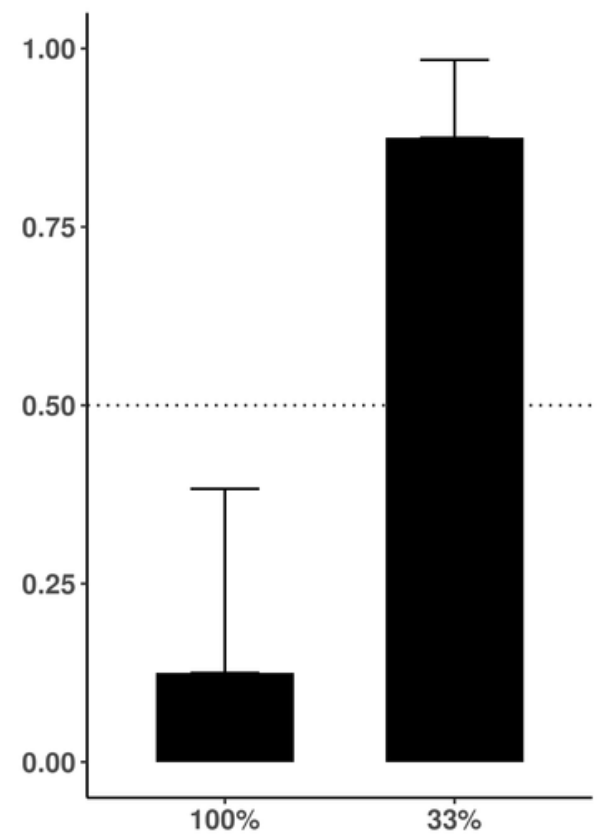

C

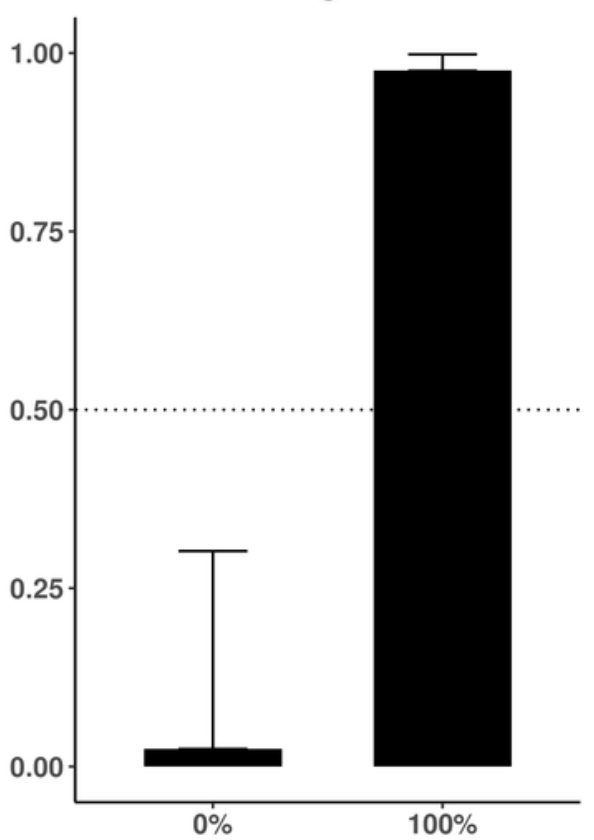

F

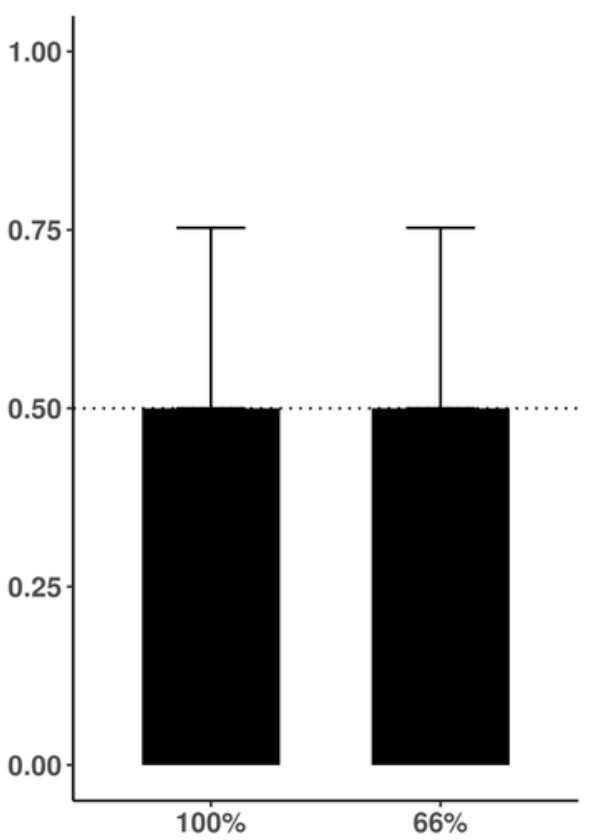




\section{Figure 4}

Figure 4.

Proportion of killer shrimp (binomial $95 \mathrm{Cl}$ ) settling in binary choice tests involving different substrates (live zebra mussel, empty shells of zebra mussel, artificial grass) tested singly (A$B, n=30$ shrimp/test) or in groups of 20 (C-D, $n=4$ tests). 
A
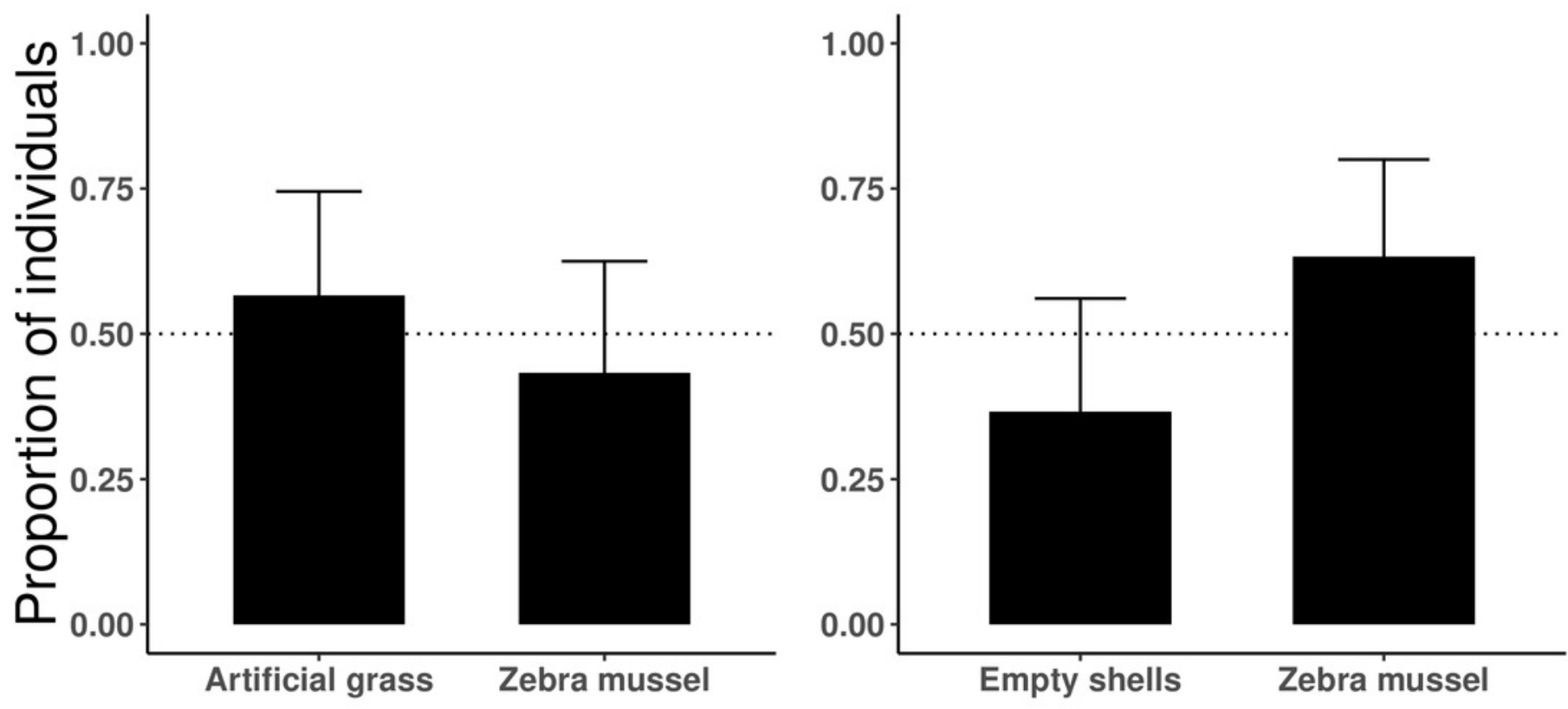

C
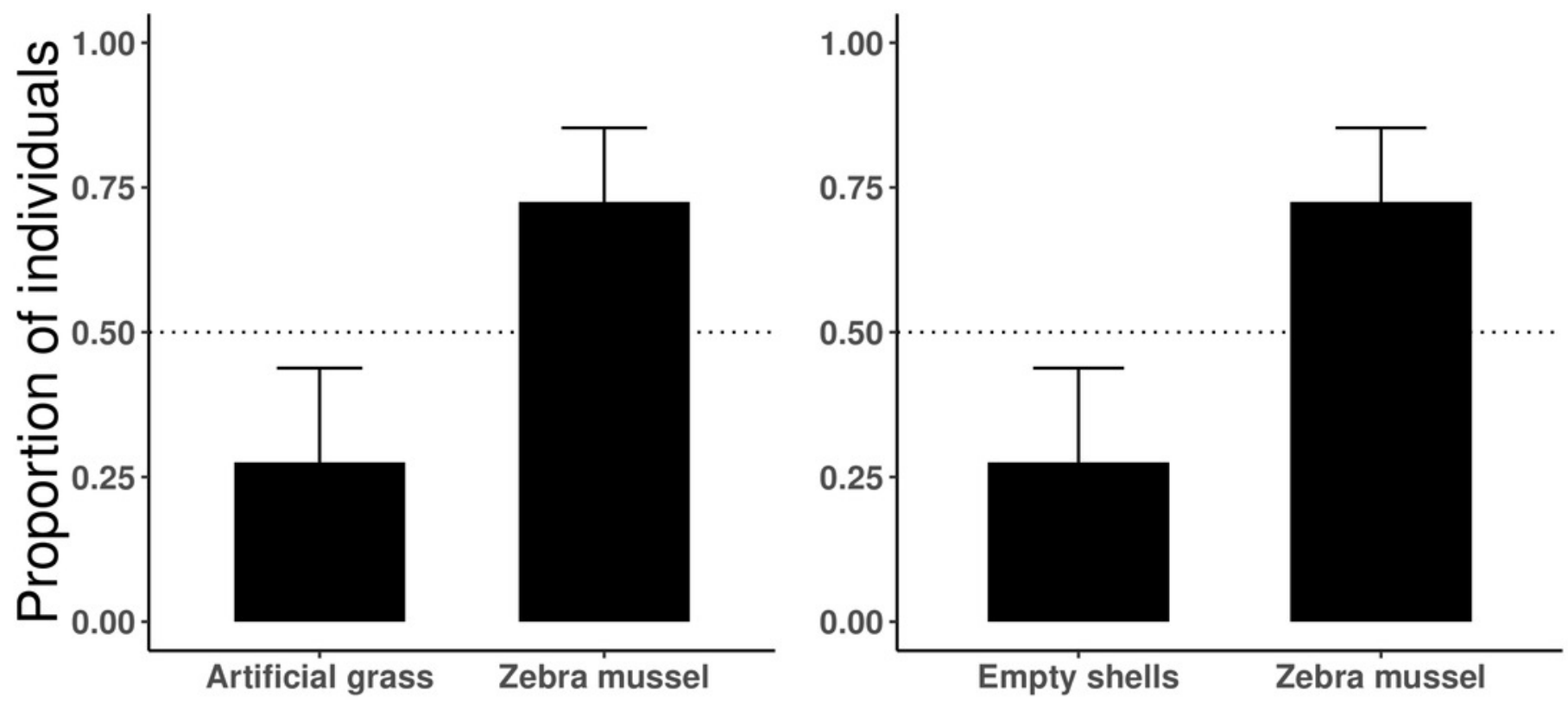


\section{Figure 5}

Figure 5

Preference by individual killer shrimp (mean time spent, $\mathrm{s} \pm 95 \mathrm{Cl}$ ) in water conditioned with different scents (blank water, $n=40$; tilapia scent, $n=40$; zebra mussel scent, $n=40$ ) from sympatric $(A, C, E ; n=60)$ and allopatric $(B, D, F ; n=60)$ populations. 

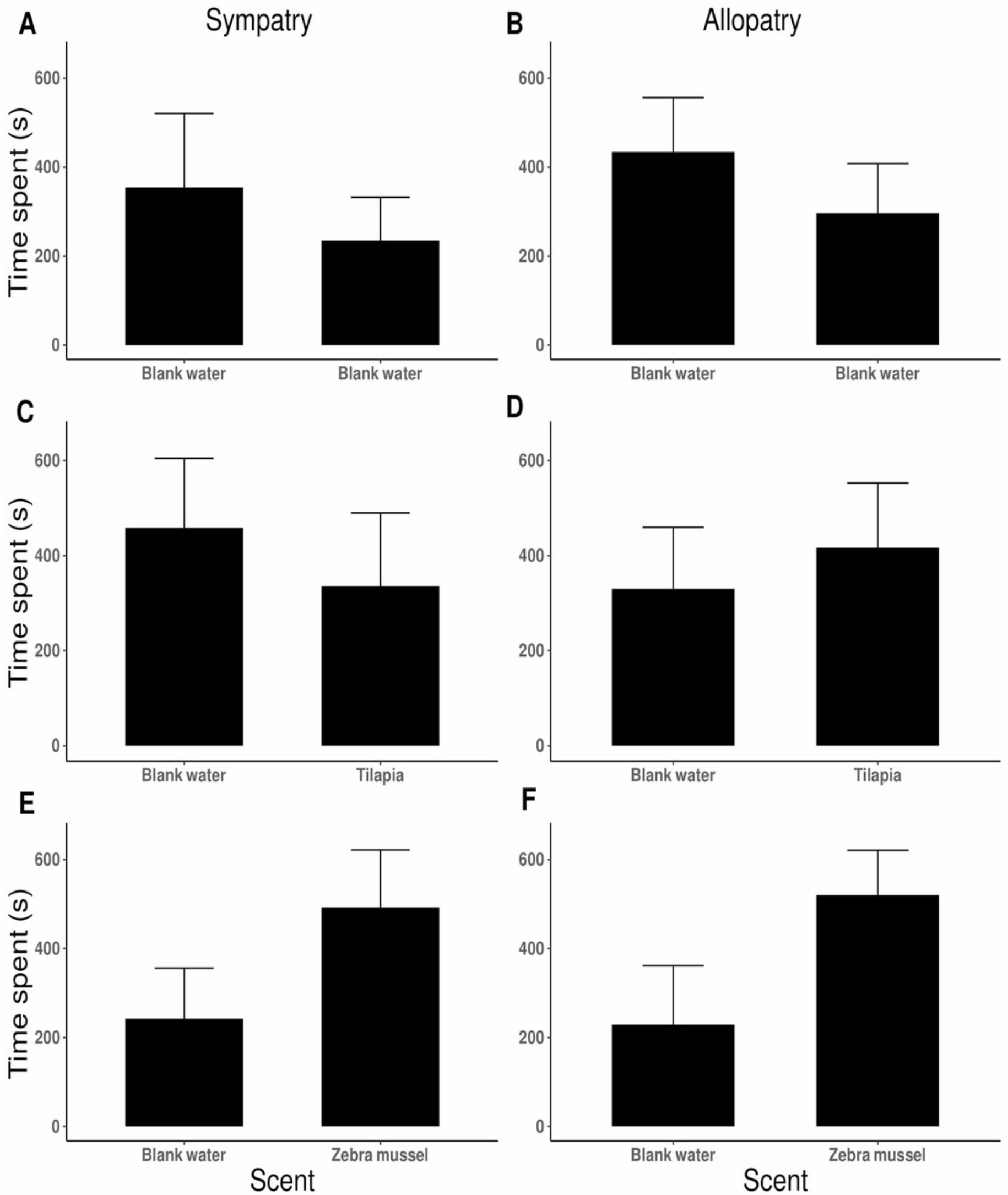


\section{Figure 6}

Figure 6

Activity (mean number of transitions $\pm 95 \mathrm{Cl}$ ) of individual killer shrimp tested in water conditioned with different scents (blank water, $n=40$; tilapia scent, $n=40$; zebra mussel scent, $n=40)$ from sympatric $(A ; n=60)$ and allopatric $(B ; n=60)$ populations. 

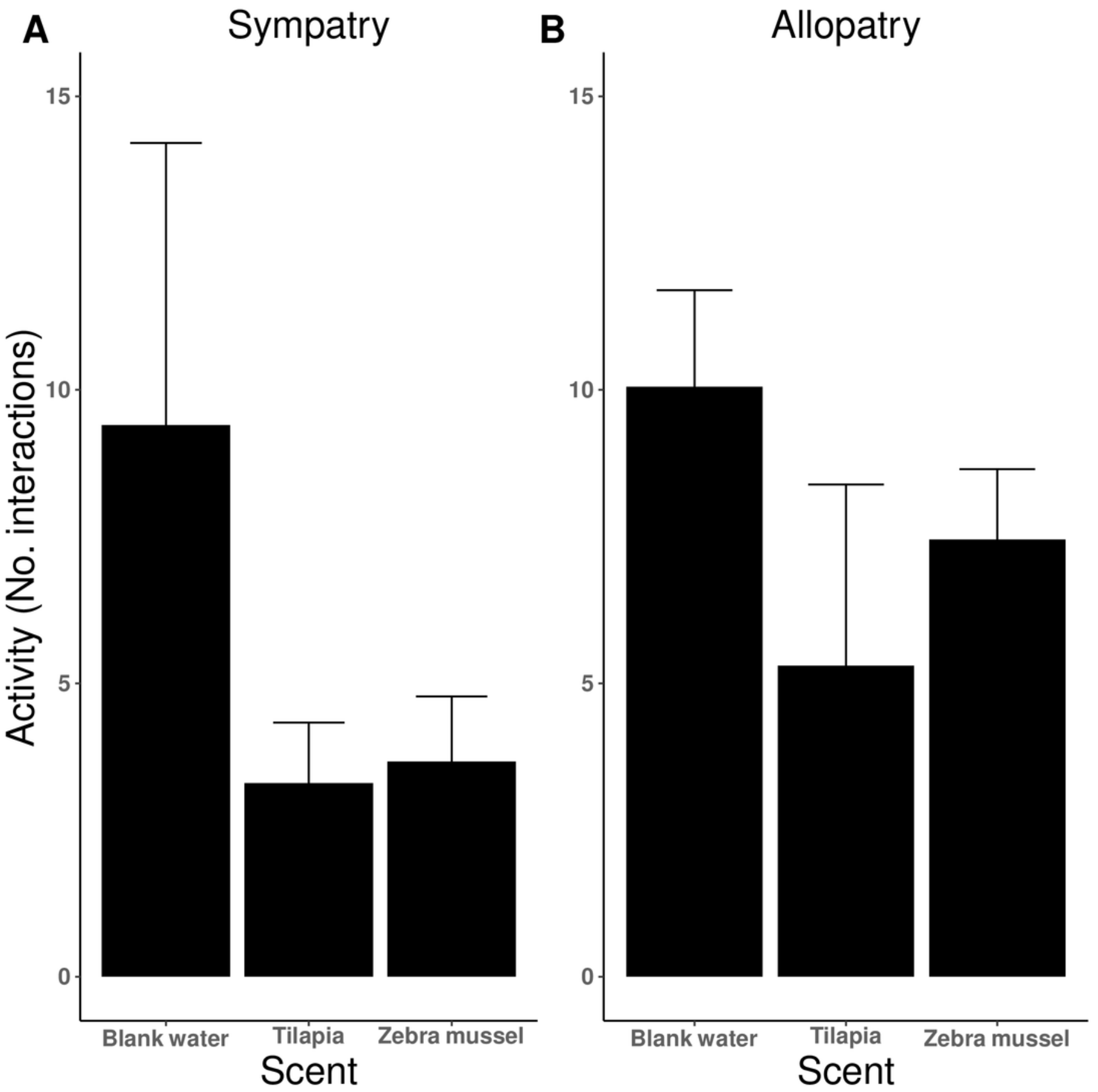